\title{
BUSINESS MODEL CANVAS NON GOVERNMENT ORGANIZATION (NGO) (CASE STUDY : RIMBAWAN MUDA INDONESIA)
}

\author{
Lukmi Ati ${ }^{* 1}$, Lukman M. Baga ${ }^{* *)}$, and Arif Satria $\left.{ }^{* * *}\right)$ \\ *) School of Business, Bogor Agricultural University \\ Jl. Pajajaran Bogor, 16151 \\ ${ }^{* *}$ Department of Agribusiness, Faculty of Economics and Management, Bogor Agricultural University \\ Jl. Agatis, IPB Dramaga Campus Bogor 16680 \\ ${ }^{* * *)}$ Department of Communication Science and Community Development, Faculty of Human Ecology, \\ Bogor Agricultural University \\ Jl. Kamper, IPB Dramaga Campus Bogor 16680
}

\begin{abstract}
Rimbawan Muda Indonesia (RMI) is an independent non-profit organization (NGO) that focuses on natural resources and environmental issues. This NGO aims to develop the conservation of natural resources. In order to achieve the vision and mission, the organization is not compatible with conducting the business model optimally, hence new strategies are needed to fix the business model. The aim of this research: (1) To identify and obtain the map (portrait) of the current RMI business model; (2) To analyse the SWOT of each element in RMI's business model; (3) To design an alternative strategy as an improvement on the current business model. This research used the combination of the Business Model Canvas (BMC) approach and SWOT matrix analysis. According to the analysis results, it could be concluded that RMI needs to conduct a business model improvement on nine BMC elements that consists of eight formulation alternative strategies including: 1) creative fund-raising strategies to the donor(s) that focus on youth and women issues, 2) one issue focus, 3) live-in community organization, 4) a fund-raising strategy by selfpromotion space roadshows and attending donor events, 5) Capacity building through knowledge sharing amongs staff both internal and inter-network, 6) Outside Java Networking development, 7) Improvement on relationship to donors through e-mails intensively and on roadshows, 8) Donor visit due to the stop of collaboration. Mentioned strategy alternatives are elaborated on the form of improvement programs that will be described in each element of business model canvas.
\end{abstract}

Keywords: business models, BMC, NGO, SWOT, RMI

\begin{abstract}
Abstrak: Rimbawan Muda Indonesia (RMI) adalah sebuah non-profit organization (NGO) independen yang memfokuskan diri pada isu sumber daya alam dan lingkungan hidup yang bertujuan mengembangkan konservasi sumber daya alam. Di dalam mencapai visi dan misinya, organisasi belum mampu menjalankan model bisnisnya dengan optimal sehingga diperlukan strategi-strategi baru untuk memperbaiki model bisnis tersebut. Tujuan dari penelitian ini: (1) Mengidentifikasi dan mendapatkan peta (potret) model bisnis RMI saat ini; (2) Menganalisis SWOT setiap elemen dalam model bisnis RMI; (3) Men-design alternatif strategi sebagai perbaikan dari model bisnis yang dijalankan saat ini. Penelitian ini menggunakan kombinasi antara pendekatan business model canvas (BMC) dan analisis matriks SWOT. Hasil analisis maka diambil kesimpulan bahwa RMI perlu melakukan perbaikan model bisnis pada sembilan elemen BMC yang terdiri dari 8 rumusan alternatif strategi meliputi: 1) strategi fund-raising yang kreatif ke donor yang fokus terhadap isu perempuan dan anak muda, 2) fokus terhadap satu isu, 3) pendampingan masyarakat secara livein, 4) Strategi fundraising melalui ruang promosi diri dengan roadshow dan menghadiri acaraacara donor, 5) Peningkatan kapasitas staf melalui sharing knowledge antar staf maupun antar jaringan, 6) pengembangan jaringan kerja di luar Jawa, 7) perbaikan hubungan dengan donor melalui email secara intensif dan roadshow, 8) Mengunjungi donor yang menghentikan kerjasama. Alternatif-alternatif strategi tersebut diuraikan dalam bentuk program-program perbaikan yang dijabarkan dalam setiap elemen dalam business model canvas.
\end{abstract}

Kata kunci: bisnis model, BMC, NGO, SWOT, RMI

\footnotetext{
${ }^{1}$ Corresponding author:

Email: lukmy.atie5@gmail.com
} 


\section{INTRODUCTION}

The role of an non-profit organization (NGO) as one of the agents of social change has had a significant improvement since 1960, especially in developing countries like Indonesia. According to Edwards (2000) the number of International NGOs increased from only 176 NGOs in 1909 to 28,000 NGOs in 1993. From this number, more than 20,000 International NGO networks are active in the world stage, and 90 percent are formed in the last three decades. Post UN Conference on 1970s, the number of NGOs has kept increasing and this conference had impacted the formation of different types of NGOs with different issues including environmental issues and sustainable development. One of the triggers for the spread for NGO is the many phenomena of donor institutions (donor-driven). According to Anheier (2002) the booming of NGO in the last years was not a coincidental matter. The process appearing was caused by the international donor institution trends that have started decentralization and disbursement of funds for NGO in developing countries that kept on improving along with the information technology growth. Until now, governments and international funding agencies kept improving their flow of development funds through NGO (Bagulay, 2014). In 1980 around US $\$ 4.7$ billion was disbursed, in 1999 it increased to US $\$ 6.5$ billion and the trend will continue to increase (Greensmith, 2002).

The increasing number of NGOs is not balanced with a good management system (Collins, 2005). According to Hernawan (2004) the achievements of NGOs are not always parallel with the practice. Based on the result of monitoring and evaluation towards several NGOs specially on the aspect of internal management and internal programs, there are several facts resulted, that is, that non-governmental organizations are still very weak in terms of managing programs (Setiawan, 1999). Other facts also stated that NGO as an alternative development agent element in the middle of their idealism to stand up for civil rights in its dynamics is actually only to fulfill donors' importance (Clark, 1995). In this matter, independence from NGO alone is very weak and NGO only moves to fulfill donors' importance (Fakih, 2010).

On the level of public trust, the perception about the transparency of the NGO world also becomes an issue in the NGO world in Indonesia (Baguley et al. 2004). The research result from Scanlon and Alawiyah (2015) stated that the public trust (government and private) to NGO is low even though the number is smaller than the condition in the previous decades. The result of the research stated that there is no enough information about the work results of NGO. On the other hand, it is also stated that NGO did not have a strong performance and financial system. It is also mentioned that most of the public stated that there is no accreditation or certification system that can provide information on the performance and documentation of the progress and results of NGO work programs in Indonesia.

The role of NGOs is very important and the development of the number of NGOs continues to increase significantly, while in other conditions, many problems often become big questions on the community about the world NGOs. This becomes the fundamental reason this research conducted. According to Greensmith (2002) currently there is no much research on NGO management compared to the management of commercial companies in general, whereas he thinks that this is no less important than commercial companies. In harmony with Greensmith, according to Sanderse (2014) there is a very few scientific study of NGOs, especially those associated with general business models. The business model for non-profit organizations (NGOs) has actually been highlighted by Dabbs (1991) who stated that studies that have noticed the growth of non-profit businesses have been largely ignored. Research in a business study is mostly done on the institution (company) profit/ commercial course. Status as a non-profit institution that makes many parties overrides the existence of this institution and it is considered not important because it does not bring any profits. On the other hand, it is less understood by the general public that the actual value of nominal funds of non-profit institutions is not much bigger in comparison with that of institutions. In 1999 the sector of NGOs or non-profit institutions had a turnover of more than US $\$ 1$ trillion globally, with the number of full-time paid employees, 19 million people. This value is equivalent with the eighth largest economy (Sanderse, 2014). According to Lambell et al. (2008) non-governmental organizations (NGOs) are still relatively absent from scientific studies especially those associated with business studies.

The approach to the canvas business models developed by Osterwalder and Pigneur (2010) is a tool of a business model concept that becomes an alternative chosen strategy. The business model is a strategic choice that 
will have operational implications, so the agency will be able to communicate, analyze, test and validate a causal relationship derived from the choice of strategy made (Shafer et al. 2005). Business Model Canvas (BMC) developed by Osterwalder and Pigneur is one approach to business model that is currently quite popular and widely used by various circles (Wiska et al. 2016). BMC has been widely discussed in previous studies. Most of the research discusses the concept of BMC focused on e-business and profit-oriented companies (Sanderse, 2014). While the development of business models for non-profit institutions is still rare. Although current studies in Business model canvas approaches are mostly found in profit-oriented businesses, the study and application of NGOs (non-profit businesses) is likely to be very different from profit-oriented businesses (Demil and Lecocq, 2010). The use of BMC tool is expected to answer all problems and deadlock related problems faced by NGOs in Indonesia so far.

This study took a case study on a NGO Rimbawan Muda Indonesia (RMI). RMI is an NGO established on September 18, 1992 in Bogor. RMI is an organization that does not go through a membership system, which has an issue orientation on environmental protection movements, natural resource management and women's rights. The existence of RMI takes part in important roles in policy-making at the national level in relation to natural resource management efforts. The condition of RMI is not much different from the condition of NGOs in general, that is, management problems, accountability, transparency and independence. This condition should be the attention on the RMI management because in the last five years the RMI conditions are still at a stagnant level. Of the total managed funds per year, it is still under five billion rupiahs. For NGOs at the RMI level, they must be able to manage funds at least 5-10 billion (Scanlon and Alawiyah, 2015). Likewise, with work locations, until now it is still in West Java and Banten only. RMI has been established for more than twentyfive years. This should be able to develop program outside Java, so that funding opportunities are greater. Starting from this condition, a mapping of the current RMI is needed, and an alternative strategy is needed so that the RMI is more developed and able to compete with other NGOs that are at the same level as HuMa, AMAN, SAINS and others.

The research at RMI is expected to represent other NGOs especially in Indonesia. Through nine elements arranged in a canvas, they can help the RMI organization describe the current business model to facilitate the creation of new strategies through improved business models. Business model improvements can fill the gap by providing some alternative business models that can be described in the form of future programs (Wheelen and Hunger 2012).

\section{METHODS}

This research was conducted at Rimbawan Muda Indonesia Bogor, West Java. The study lasted for 4 months from January to April 2017. Data collected consisted of primary and secondary data. The data collected to view the existing condition of RMI consisted of primary and secondary data. Primary data collection used techniques of direct observation, filling out questionnaires, in-depth interviews (indepth interview) and Focus Group Discussion (FGD) in the internal organization. While secondary data were obtained from annual reports on RMI and library materials that are relevant to the research. The literature consists of journals, theses, dissertations, books and studies of research that have been done before.

Data collection techniques for classification of strengths, weaknesses, opportunities and threats (SWOT) were filling out questionnaires, in-depth interviews and FGDs onto internal and external organizations. Data collection from internal organization of Focus Group Discussion (FGD) are determined by the selection of internal and external strategic factors, while data collection onto the external parties of questionnaires represented foreign donors, Indonesian donor agencies (grand making institutions), and partners /networks of RMI. In-depth interviews were conducted to assisted communities, assisted community leaders/village heads in a structured manner that referred to the prepared questionnaires.

Method of data analysis was conducted to know condition of existing organization, an analysis of the environment and internal business activities of organization by using business model canvas framework developed by Osterwalder and Pigneur (2010). This business framework is a canvas that divides the business model into nine main boxes (Figure 1). 


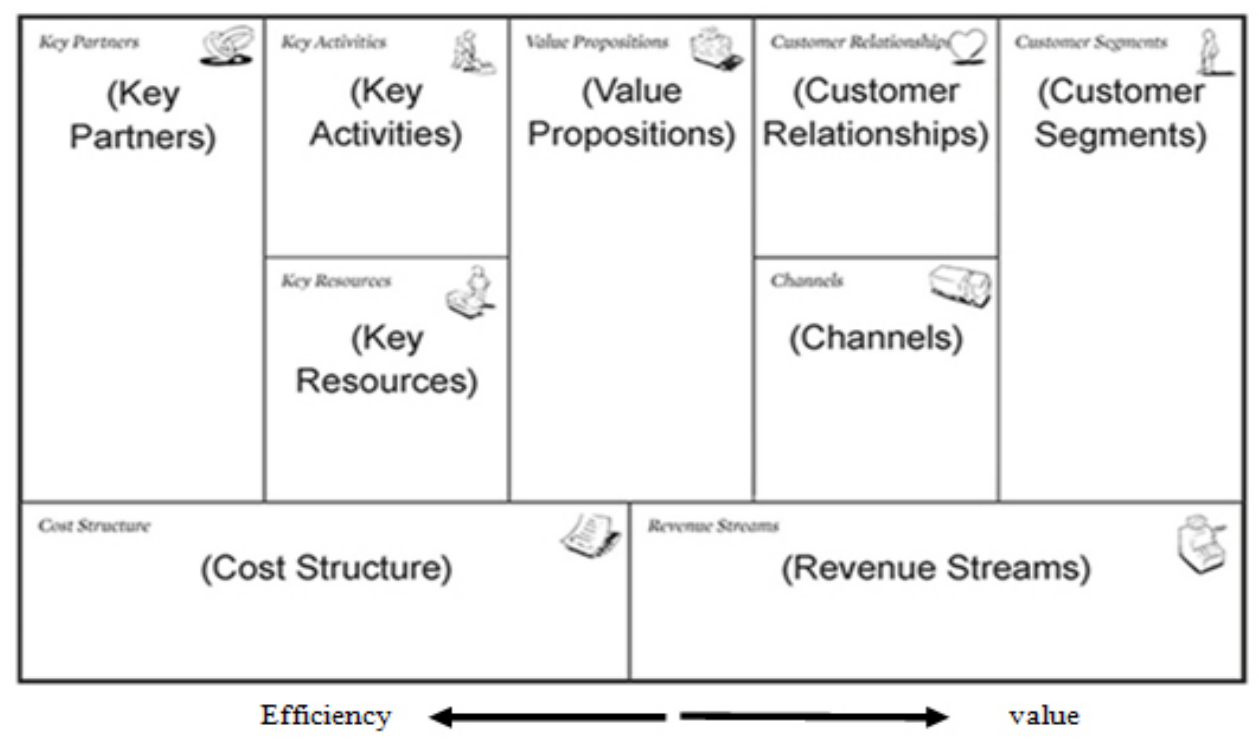

Figure 1. Business Model Canvas (Osterwalder and Pigneur, 2014)

The next method of analysis is the identification and evaluation of factors affecting both internal and external organizational environments on each element that has been mapped in the business model canvas of RMI the current. Each element in the business models of canvas box is done with SWOT analysis (Strengths, Weaknesess, Opportunities, Threats). The mapping results by looking at the strengths, weaknesses, opportunities and threats are selected or rated on each internal and external factors to determine strategic issues through the SWOT matrix by marrying the strengths with the opportunities (SO strategy), the strengths with the threats (ST strategy), the weaknesses with opportunities (WO strategy) and weaknesses for threats (WT strategy) (Rangkuti, 2015).

The last method of analysis was to combine map of business model canvas with SWOT analysis result. The combination of these two analytical tools could be complementary, in which BMC is used to assess the overall integration of business models and SWOT is used to look at all the components of these elements in depth so as to provide an alternative direction of an effective business model strategy. In general, the outline of the research framework is presented in Figure 2.

\section{RESULT}

\section{Portrait of the current RMI Business Model}

Customers segments of RMI consist of assisted communities (Bogor, Lebak and Sukabumi district). The communities are the main customers as the beneficiary directly from the activities undertaken by RMI, but they do not provide income. The area covered by RMI includes indigenous territory (3 indegenous areas), rural / local area (25 villages spread in 2 provinces and 3 districts). This group includes groups of men, women and youth. The second customer segments are donor agencies. Donors are second customers as customers that bring RMI value streams directly. Donors that provide RMI's current funding support are Terre des Hommes Germany, Terre des Hommes BMZ, Partnership and MCC through MCAI.

Value propositions that RMI offers to its customers is to have an eco-populism flow. This value becomes the identity of the RMI that distinguishes it from other NGOs. Customers can easily understand that the RMI is an environmental movement activist that is very pro-people, the environment for the welfare of society. Another unique value offered by RMI to the beneficiary community (constituents) is direct assistance in grassroots. RMI is the only NGO in Jabodetabek (Jakarta, Bogor, Depok, Bekasi) area with the core of community empowerment which has the nearest learning location as the basis of organization 
work. Another value of RMI offers to donors is that RMI has integrated issues ranging from environmental, social, economic and comprehensive gender issues to work strategies ranging from community assistance, critical education to advocacy (regional and national). The RMI target group also touches on governments, women, elites, youth and even children.

The channel used to communicate the value proposition of the RMI to the public is through direct communication by word of mouth. Other channels that are used are through sms and phone but they are still very limited and only to communicate with community leaders only. The channels used to communicate with donors are via email and website. Donor emails are limited to proposal-only relationships and program reporting. Website used is also still rarely updated.

Customer relationships built by RMI to customers are more on personal and inter-group relationships. The relationship to the community is more emphasized on personal relationships based on the needs of the community. Direct guidance of the community becomes important to maintaining relationships to the immediate constituents. In addition, regular meetings or discussions are also often conducted in the community whether they are related to the project or not. While the relationships built with donors are more on interpersonal relationships and are emphasized on how funding to support is sustainable even though this relationship is currently limited to the relationship of the proposal and reporting program only.

The largest RMI revenue streams are from donors (above 90\%). Donors that provide funding support so far consist of domestic donors: partnerships, and overseas donors: Terre des Hommes BMZ, Terre des Hommes Germany and MCC through the MCAI program. This funding source is used to run the activities as an effort to achieve the mission of the institution and of course according to agreement with the donor and for routine operational funding (staff salary, utilities cost).

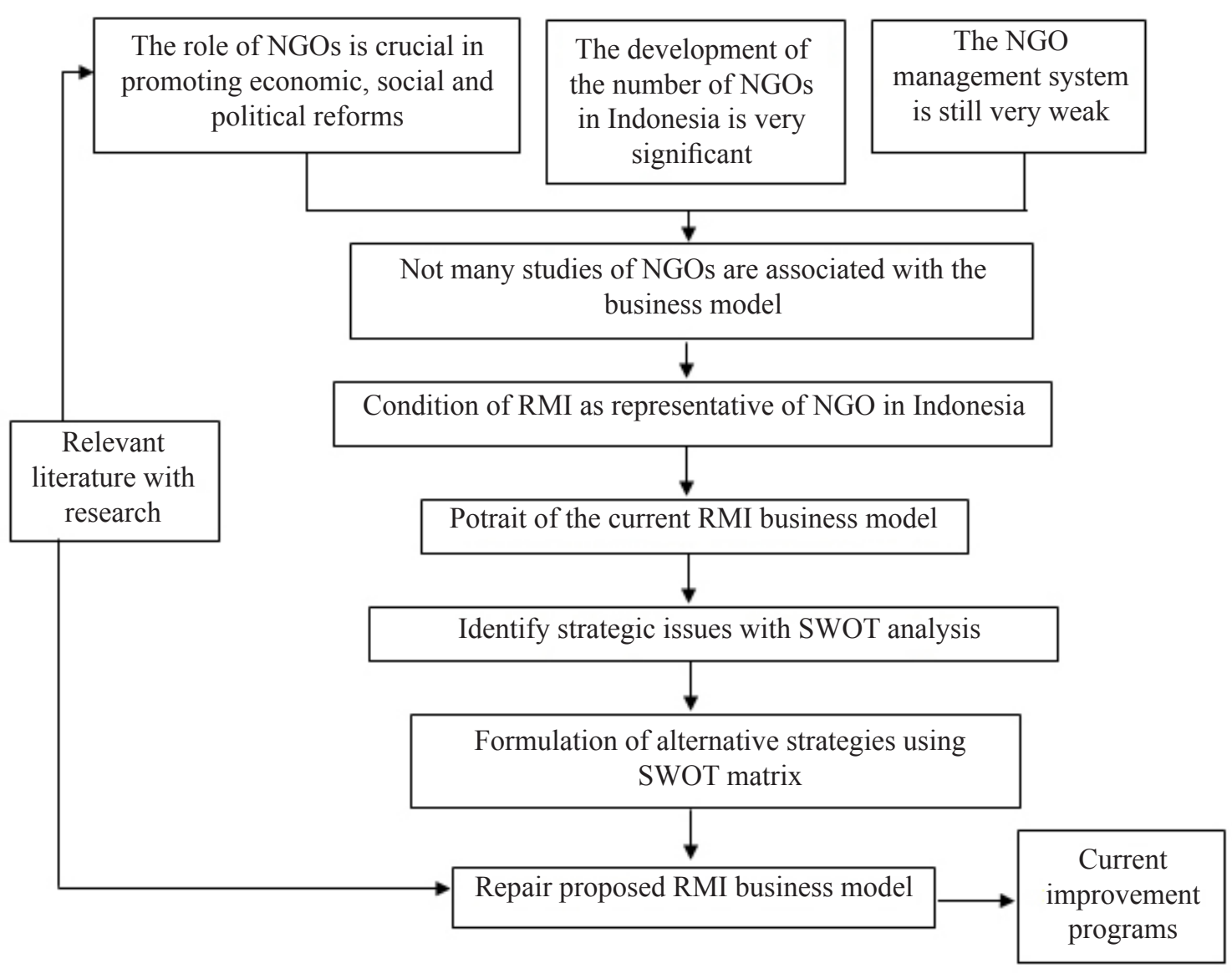

Figure 2. Research framework 
RMI's key resources to run activities in order to offer its current value propositions include Human Resources (HR) in total of 22 people with different education levels and varying capacities so that there is still a high gap among knowledges. Other resources are integrated organizational structures, intellectual resources, such as databases, funding sources and sound management systems, with a customized organizational structure and supported by documented SOPs.

Key activities undertaken by RMI consist of community assistance as capacity building efforts, policy advocacy undertaken together with other network partners (NGOs), knowledge management, and networking with other NGOs.
Key partnerships contributing to the achievement of the objectives and vision of the RMI mission are at the national level: HuMa, EPISTEMA Institute, Sajogyo Institute, Jaringan Kerja Pemetaan Partisipatif (JKPP), Jaringan Pendidikan Lingkungan (JPL), Aliansi Masyarakat Adat Nusantara (AMAN), Partnership, Badan Registrasi Wilayah Adat (BRWA), Konsorsium Pembaruan Agraria (KPA) and at international level: International Land Coalition (ILC) and Working Group Bio (WGB).

Cost structures of activities undertaken by RMI include the cost of activities for program implementation, operational costs which are the cost of staff salaries and utilities costs. The portrait of the current business model canvas run by RMI is presented in Figure 3

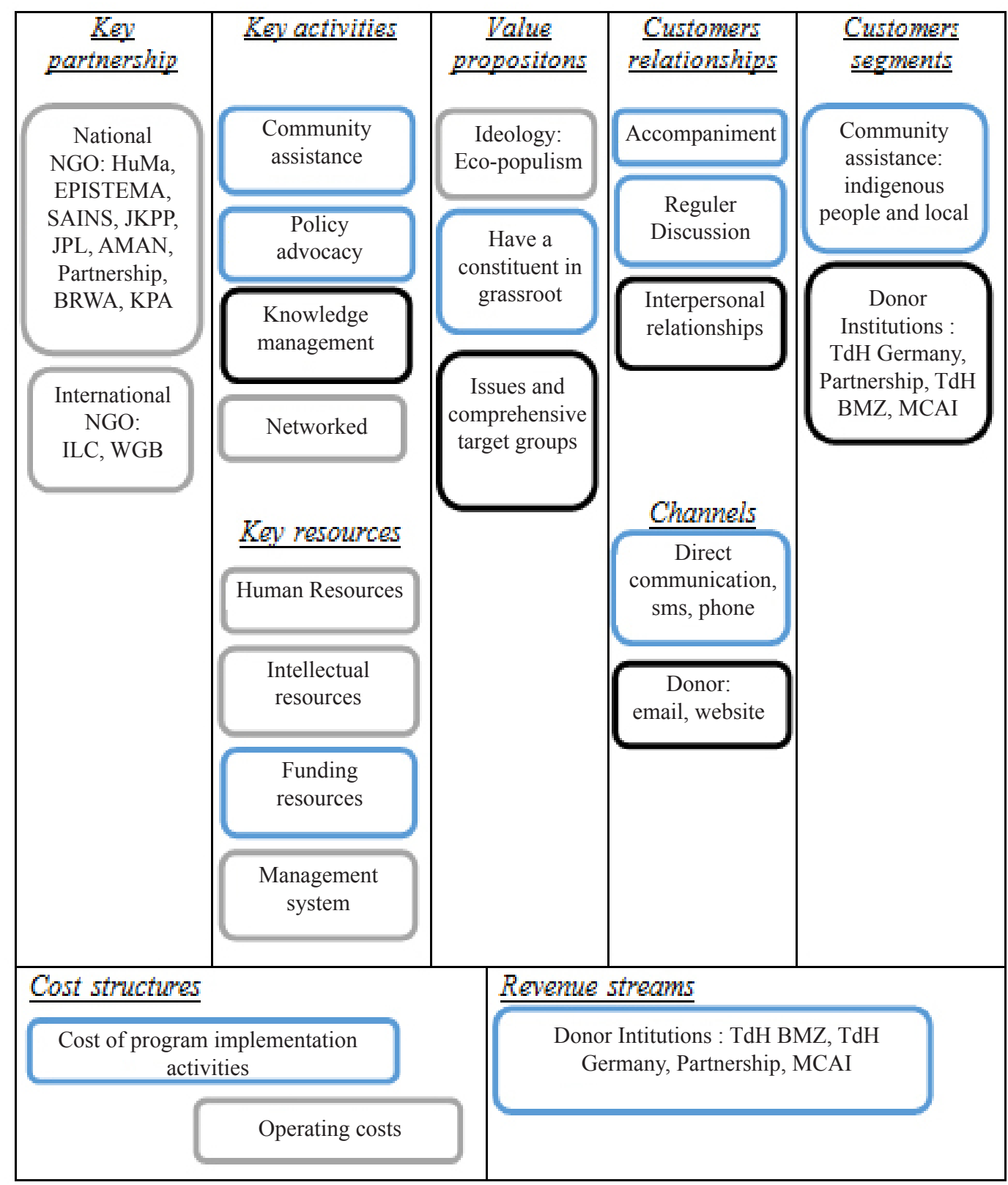

Figure 3. The current of RMI Business Model Canvas (blue: representative customer segment community; black: representative customer segment donor) 


\section{SWOT assessment on each element of RMI business model}

The stages performed after mapping the current RMI business model is to perform SWOT analysis of each element on the nine elements that have been mapped. Mapping the strengths, weaknesses, opportunities and threats to each of these elements will be used to develop strategies to improve the business model that has been done so far. Mapping on the nine elements will be combined with the results of the SWOT analysis in order to obtain more in-depth and sharper analysis results. The results of the SWOT assessment analysis on the nine elements in the RMI model business are presented in Table 1.

\section{SWOT Matrix Analysis}

Based on the SWOT analysis of each subsequent element in the SWOT matrix analysis, it can be determined alternative improvement strategies. The SWOT matrix analysis that has been plotted produces eight strategies that can be used by RMI in developing future strategies. The results of the SWOT matrix analysis are explained in Figure 4.

Table 1. SWOT assessment on the nine elements of the RMI Business Model

\begin{tabular}{|c|c|c|c|c|}
\hline Element & Strengths & Weaknesses & Opportunities & Threats \\
\hline $\begin{array}{l}\text { Customer } \\
\text { segments }\end{array}$ & $\begin{array}{l}\text { - Direct assistance in the } \\
\text { community } \\
\text { - Implement the project } \\
\text { according to the needs of } \\
\text { the community }\end{array}$ & $\begin{array}{l}\text { - Lack of communication } \\
\text { with donors } \\
\text { - Assistance in the } \\
\text { communities has not been } \\
\text { intensive }\end{array}$ & $\begin{array}{l}\text { - Assistance in the } \\
\text { community at the request } \\
\text { of the community } \\
\text { - Funding opportunities from } \\
\text { donors }\end{array}$ & $\begin{array}{l}\text { - Many NGOs enter the } \\
\text { RMI worksite } \\
\text { - Donors suspend project }\end{array}$ \\
\hline $\begin{array}{l}\text { Value } \\
\text { propositons }\end{array}$ & $\begin{array}{l}\text { - Constituents in grassroots } \\
\text { - Have strong ideals } \\
\text { - The issues are } \\
\text { comprehensive }\end{array}$ & $\begin{array}{l}\text { - Lack of focus on } \\
\text { developing issues } \\
\text { - Have not been able to } \\
\text { package the concept well }\end{array}$ & $\begin{array}{l}\text { - Many communities outside } \\
\text { Java need assistance } \\
\text { - Few competitors at the } \\
\text { same location }\end{array}$ & $\begin{array}{l}\text { - The presence of other } \\
\text { NGOs with similar issues } \\
\text { - Rejection from the } \\
\text { communities }\end{array}$ \\
\hline Channels & $\begin{array}{l}\text { Own media website, FB, } \\
\text { Twitter }\end{array}$ & $\begin{array}{l}\text { The use of media networks } \\
\text { is still limited }\end{array}$ & $\begin{array}{l}\text { Social media is used by } \\
\text { many parties }\end{array}$ & $\begin{array}{l}\text { There are news/issues that } \\
\text { are more interesting in the } \\
\text { public }\end{array}$ \\
\hline $\begin{array}{l}\text { Customers } \\
\text { Relationships }\end{array}$ & $\begin{array}{l}\text { - The closeness of the } \\
\text { relationship of the } \\
\text { community } \\
\text { - Close donor relationships }\end{array}$ & $\begin{array}{l}\text { - Relations between } \\
\text { donors are still limited to } \\
\text { reporting and proposals } \\
\text { - Lack of self-promotion } \\
\text { space }\end{array}$ & $\begin{array}{l}\text { - Personal relationship with } \\
\text { the community }\end{array}$ & $\begin{array}{l}\text { - Donor distrust with RMI } \\
\text { - Personal/staff changes to } \\
\text { old donors }\end{array}$ \\
\hline $\begin{array}{l}\text { Revenue } \\
\text { streams }\end{array}$ & $\begin{array}{l}\text { Efficient financial } \\
\text { management }\end{array}$ & Weak fund-raising strategy & $\begin{array}{l}\text { The existing funding } \\
\text { opportunities that are still } \\
\text { open from donors }\end{array}$ & Many unexpected costs \\
\hline Key resources & $\begin{array}{l}\text { Well capacity of staff in } \\
\text { managing programs and } \\
\text { finance }\end{array}$ & $\begin{array}{l}\text { - Inexperienced board skills } \\
\text { - Uneven human resources } \\
\text { capacity (high gap) }\end{array}$ & $\begin{array}{l}\text { High outsiders' confidence } \\
\text { in some of the staff }\end{array}$ & $\begin{array}{l}\text { - Staff hijacking by other } \\
\text { parties } \\
\text { - Piracy of rmi data by } \\
\text { other agencies }\end{array}$ \\
\hline Key activities & $\begin{array}{l}\text { - Independent organization } \\
\text { - Having a neat strategic } \\
\text { plan }\end{array}$ & $\begin{array}{l}\text { - Monitoring evaluation } \\
\text { system not good } \\
\text { - Assistance in community } \\
\text { is not live-in }\end{array}$ & $\begin{array}{l}\text { The work location of RMI } \\
\text { becomes the location of } \\
\text { comparison study (domestic } \\
\text { and foreign) }\end{array}$ & $\begin{array}{l}\text { There are policies that } \\
\text { contradict the mission of } \\
\text { the organization }\end{array}$ \\
\hline $\begin{array}{l}\text { Key } \\
\text { partnerships }\end{array}$ & $\begin{array}{l}\text { Strong network to develop } \\
\text { policies }\end{array}$ & $\begin{array}{l}\text { - National network is still } \\
\text { limited (Jabodetabek) } \\
\text { - Network-related } \\
\text { relationships }\end{array}$ & $\begin{array}{l}\text { The existence of similarity } \\
\text { issues with the network }\end{array}$ & $\begin{array}{l}\text { Disagreements with the } \\
\text { network }\end{array}$ \\
\hline $\begin{array}{l}\text { Cost } \\
\text { structures }\end{array}$ & $\begin{array}{l}\text { Good financial } \\
\text { management }\end{array}$ & $\begin{array}{l}\text { Many unallocated costs of } \\
\text { the project budget }\end{array}$ & $\begin{array}{l}\text { Capacity building } \\
\text { opportunities for } \\
\text { organizational fund } \\
\text { management }\end{array}$ & Swelling costs \\
\hline
\end{tabular}




\begin{tabular}{|c|c|c|}
\hline External Factors & $\begin{array}{l}\text { Strengths (S) } \\
\text { 1. Direct assistance in the community } \\
\text { 2. The capacity of staff to manage } \\
\text { programs and finance is good } \\
\text { 3. An independent organization } \\
\text { 4. Have a strong network to develop } \\
\text { policies }\end{array}$ & $\begin{array}{l}\text { Weaknesses (W) } \\
\text { 1. Not focus on existing issues } \\
\text { 2. Assistance in the community has } \\
\text { not been intensive } \\
\text { 3. Fund raising strategies is still weak } \\
\text { 4. The network is limited to Jabo- } \\
\text { detabek }\end{array}$ \\
\hline $\begin{array}{l}\text { Opportunities (O) } \\
\text { 1. The community considers that RMI } \\
\text { is "a good NGO" } \\
\text { 2. Many funding opportunities from } \\
\text { donors that match the RMI issue } \\
\text { 3. Many other parties believe in the } \\
\text { performance of RMI staff }\end{array}$ & $\begin{array}{l}\text { S-O Strategy } \\
\text { 1. Submitting proposals to potential } \\
\text { donors that match the vision and } \\
\text { mission of the organization by } \\
\text { capable staff together with suitable } \\
\text { networks (S1, S2, S3, S4, O2) } \\
\text { 2. Increasing staff capacity by shar- } \\
\text { ing knowledge between staff and } \\
\text { networks, so that the public increas- } \\
\text { ingly believe in RMI performance } \\
\text { (S2, S4, O3) }\end{array}$ & $\begin{array}{l}\text { W-O Strategy } \\
\text { 1. Focus on one issue so that funding } \\
\text { opportunities from donors are also } \\
\text { focused (W1, O2) } \\
\text { 2. Intensive assistance (live-in) } \\
\text { because the community believe in } \\
\text { RMI (W2, O1) } \\
\text { 3. Fund raising strategies through self- } \\
\text { promotion space with roadshows } \\
\text { to potential donors and attending } \\
\text { events organized by donors (W3, } \\
\text { O2) } \\
\text { 4. Expand networks with local NGOs } \\
\text { outside Java (Kalimantan, Sumatra } \\
\text { and Eastern Indonesia) (W4, O3) }\end{array}$ \\
\hline $\begin{array}{l}\text { Threats (T) } \\
\text { 1. Donors suspend the projects } \\
\text { 2. Personal changes in old donors } \\
\text { 3. Conflict of interests in the network }\end{array}$ & $\begin{array}{l}\text { S-T Strategy } \\
\text { Visiting donors that have stopped col- } \\
\text { laboration and donors who have new } \\
\text { staff, assure them that RMI is able to } \\
\text { manage programs and finances well } \\
\text { and have a strong network }\end{array}$ & $\begin{array}{l}\text { W-T Strategy } \\
\text { Strengthen networks of Jabodetabek by } \\
\text { regular discussions, and try to resolve } \\
\text { to exist conflicts (W6, T3) }\end{array}$ \\
\hline
\end{tabular}

Figure 4. RMI SWOT Matrix

\section{Improvement of RMI business models}

Based on the results of SWOT RMI analysis that has been mapped there are some things that need to be refined as an improvement effort of RMI management which becomes more effective and efficient in the future. To get optimal funding support RMI needs to do fund-raising strategy to donor. Identification and approach to potential donors of both old donors and new donors in accordance with the RMI issues, such as donors focusing on women's issues: International Land Coalition, HIVOS, UNDP, Brot Für die Welt (Bread for the World), The Norwegian Human Rights Fund (NHRF), TIFA, UN Woman, IWE-WELDD, Global Fund for Woman, Mamacash, DFID, Ford Foundation and donors focusing on child issues: Terre des Hommes, Project Concern International and World Vision International.
The current condition of RMI has a comprehensive issue. With the comprehensive issues of RMI being out of focus, sometimes the issues that evolve are simply ignored. The strategy that needs to be changed is that RMI should focus on a growing issue. The choice of current issues is the issue of youth and women. The choice of issues of youth and women is based on the greatest expertise of current RMI and current trending issues. Focusing issues with youth and women with integrated community empowerment strategies through intensive facilitation will be a new strength for the RMI and can easily prepare proposals to be submitted to potential donors. Identifying donors that focus on issues of youth and women will be easier.

The limitation communication channel of RMI's with its customers needs to be improved to make communication more effective and efficient. The mapped strategy is to go to donors that have stopped long term collaborations and donors with new 
personalities. An effective communication channel for delivering agency information about donors is through direct communication with roadshows. Channels or other media that can be used to connect with donors can be through a website that is always updated by presenting information about RMI clearly about the vision, mission, programs that is being run as well as issues developed.

Customer relationships built by RMI are currently very limited, especially to donors. The formulation of the resulting strategy needs to communicate with donors that has stopped cooperation and donors with new personal reimbursements. Needs to improve the relationship between donors is through email regularly and send information about RMI (organization profile) especially to old donors that never again communicate. Another relationship that can be established is through direct communication by visiting a potential donor office (road show). Excavation of information on why long donors stop cooperation needs to be explored more deeply. This is an attempt to correct the lack of RMI that donors do not satisfy.

In order to realize the sustainability of the institution, a creative fund-raising strategy is needed. Currently donors that support RMI are still very limited while there are still many funding opportunities in other donors that are still open. Fund raising strategies are needed through self-promotion events, roadshows to potential donors, sending an attractive organization profile to donors via email and through the RMI website that is constantly updated on RMI's work programs so that donors are fully informed by RMI. The strategy for obtaining other funding sources is to revive the business unit currently owned by RMI.

One of RMI's key resources is the database which contains all data and information about the assisted areas and the results of work achieved. Seeing the importance of resources in the form of this database it is necessary to improve the data management system in RMI which is currently still very minimal and managed by a competent special staff. This intellectual resource is in the need because it becomes a tool to achieve customer satisfaction both community and donor. With well-documented data, RMI will be able to explain the program well in accordance with valid data sources.
The strength of RMI's key activities is the assistance and community organizing that is different from other NGOs, especially in Jabodetabek. The only on-off mentoring strategy should be improved immediately on a live-in assistance strategy. Improvements to assisting strategies with live-in or living with communities should be immediately undertaken by a capable Community Organizer (CO) that is sensitive to the situation in the community and understands the growing issues associated with the region being accompanied. Strategy accompanied by placing one person-one village can also be a strategy to be able to focus on optimal results.

Key partnerships or networks for NGOs including RMI work are parties that participate in the achievement of the vision and mission of the organization. RMI's current network is limited to NGOs in Jabotabek and Lombok only. Improvement needs to be done is a strategy to open the network of partners outside Java. This needs to be done because some donors only support locations outside Java such as Sumatra, Kalimantan and Nusa Tenggara. This effort needs to be done at the same time for the development of RMI work site area. In addition, current donor trends favor consortium work in which national NGOs consortium with local NGOs and spread in several provinces. This strategy is being undertaken as an effort to capture donor funding opportunities. The network of Jabodetabek is used as a network in policy advocacy because it is adjacent to the capital, while the network outside Jabodetabek is a network of the implementation of programs in the field.

RMI's current cost structure is the cost of program implementation and operational costs. Allocation of unallocated cost to support alternative strategy formulation is network cost, capacity building staff cost. The allocation of costs for capacity building of staff needs to be budgeted specifically because the staff is the main key resource that determines the success of the program. Other costs that should be specifically allocated are networking costs. This is in harmony with the result of strategy formulation whereby expanding the network becomes a crucial thing that must be done immediately. Improvements to the RMI business model are shown in Figure 5. 


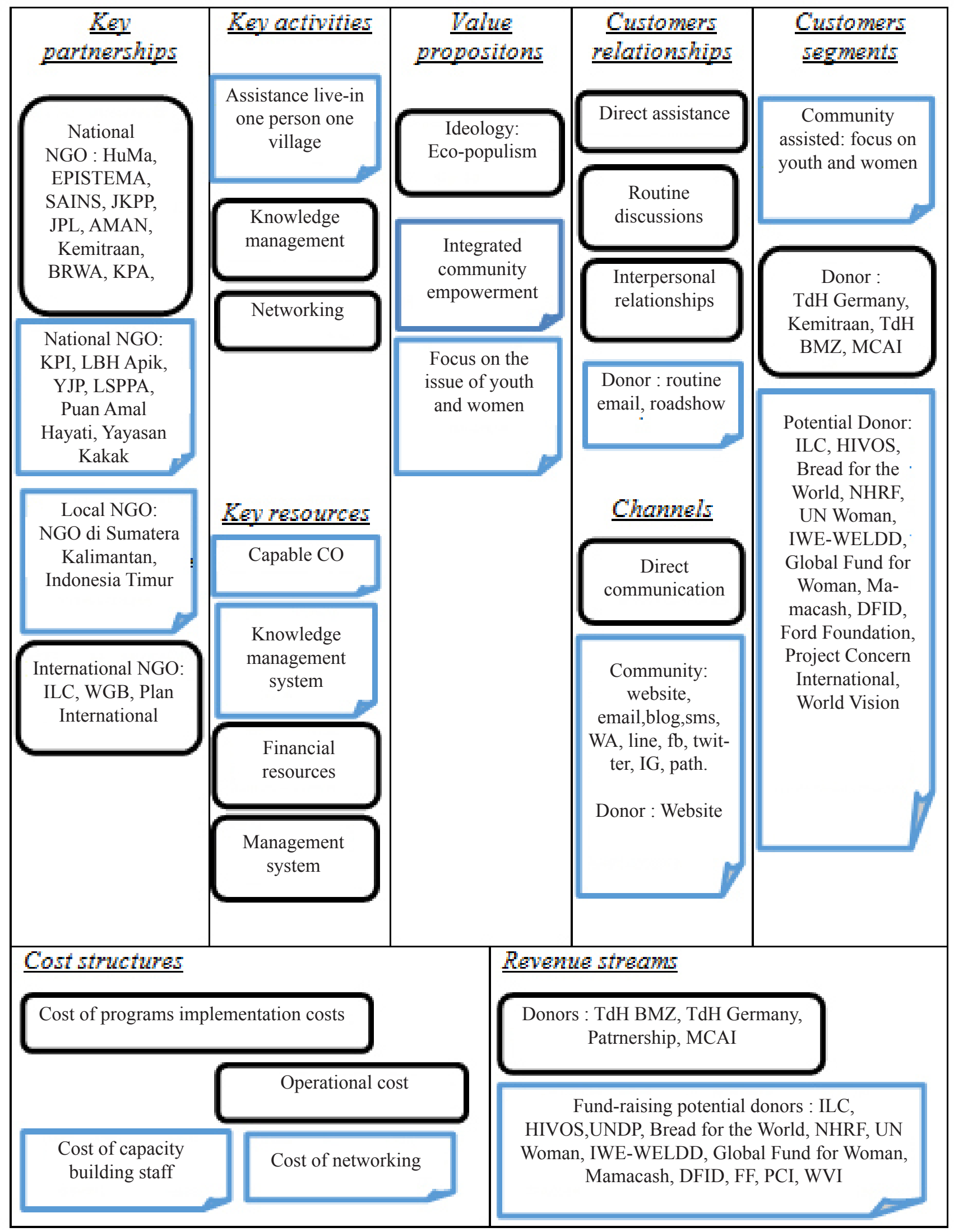

Figure 5. Improvement to the business model of RMI (blue) 


\section{Managerial Implication}

The results of this study provide an overview to Rimbawan Muda Indonesia about the business model that is now implemented, so the organization knows what needs to be improved. The recommended of the business model canvas improvement aims to minimize strategic issues that threaten on the organization sustain. Applying alternative strategies and programs obtained from the results of the analysis can help organizations (RMI) conduct organizational reforms so that it has an impact on develop the organization in the future. Things to do are: a) increasing staff capacity through special training in accordance to staff capacity, with capable staff then donor trust will increase; b) reforming the strategy, namely focusing on one issue, so that the RMI value proposition is more unique (specialization); c) conducting creative fund-raising strategies that attract donors.

\section{CONCLUSIONS AND RECOMMENDATIONS}

\section{Conclusions}

Based on the result of research about business model canvas analysis of NGO with a case study of Indonesian Rimbawan Muda (RMI), it can be concluded that at this time it is needed improvement to nine elements of business model run by RMI. The alternative strategies generated from the SWOT matrix consist of 8 alternative strategy formulas including (1) creative fund-raising strategies to the donor(s) that focus on youth and women issues, (2) one issue focus, (3) livein community organization, (4) a fund-raising strategy by self-promotion spaces roadshows and attending donor events (5) Capacity building through knowledge sharing among staff both internal and inter-network, (6) outside Java Networking development, (7) donor visit due to the stop of collaboration (8) donor visit du to the stop of cooperation.

\section{Recommendations}

RMI management must immediately improve the internal management, especially about capacity building of staff and reform issues to be specific so that they are focused and easy to manage. For further research, it is necessary to compare with other non-government organizations that have different organizational strategies and issues.

\section{REFERENCES}

Anheier HK. 2010. Non-Profit Organizations. Theory, Management, Policy. London: Routledge.

Baguley JM, Cornforth C, Mallory G. 2004. What Drives Non-Govermental Organization (NGOs) to Internationalise? In 33rd Annual ARNOVA Conference; 2014 November; Los Angeles, USA. Los Angeles: University Business School.

Clark J. 1995. NGO dan Pembangunan Demokrasi. Yogyakarta: Tiara Wacana.

Collins J. 2005. Good to Great and the Social Sectors: A Monograph to Accompany Good to Great. Boulder: Self-Published.

Dabbs G. 1991. Nonprofit businesses in the 1990s: Models for success. Business Horizons 34(5):68-71. https://doi.org/10.1016/00076813(91)90051-V.

Demil B, Lecocq X. 2010. Business model evolution: In search of dynamic consistency. Long Range Planning 43: 227-246. https://doi.org/10.1016/j. 1rp.2010.02.004.

Edwards M. 2000. NGO Rights and Responsibilities: A New Deal for Global Governance. London: The Foreign Policy Centre.

Fakih M. 2010. Masyarakat Sipil untuk Transformasi Sosial. Yogyakarta: INSIST Press.

Greensmith J. 2002. Trends in fundraising and giving by international NGOs. International fundraising congress; 2002 September; New York, USA. New York: Global Policy Forum.

Hernawan D. 2004. Akuntabilitas NGO dan kontrol publik. Jurnal Administrasi Publik 3(2).

Lambell R, Ramia G, Nyland C, Michelotti M. 2008. NGOs and international business research: Progress, prospects and problems. International Journal of Management Review 10:75-92.https:// doi.org/10.1111/j.1468-2370.2007.00218.x.

Osterwalder A, Pigneur Y. 2010. Business Model Generation. Toronto: Self-published.

Osterwalder A, Pigneur Y. 2014. Business Model Canvas: Penerapan di Indonesia. Jakarta: PPM.

Rangkuti F. 2015. Analisis SWOT: Tehnik Membedah Kasus Bisnis. Jakarta: PT Gramedia Pustaka Utama.

Sanderse J. 2014. The Business Models Canvas of NGOs. Germany: Facultiet Managementwetenschappen.

Scanlon MM, Alawiyah T. 2015. Sektor NGO di Indonesia : Konteks, konsep dan profil terkini. Jakarta: Department of Foreign Affairs and 
Trade/DFAT Australia.

Setiawan B. 1999. Ornop dalam Gerakan Masyarakat Sipil: Analisis Terhadap Reposisi Peran Ornop Pasca Rezim Soeharto. Yogyakarta: Pustaka Pelajar.

Shafer SM, Smith JH, Linder JC. 2005. The power of business models. Business Horizon 48: 199-207. https://doi.org/10.1016/j.bushor.2004.10.014.
Wheelen TL, Hunger JD. 2012. Strategic Management \& Business Policy. Toward Global Sustainability. 13th Ed. New Jersey: Pearson.

Wiska F, Syarief R, Baga LM. 2016. Developing "sekolah peternakan rakyat" program using the business model canvas approach (Case Study: Bojonegoro Regency). Indonesian Journal of Business and Entrepreneurship 2(2):69-81. https://doi.org/10.17358/IJBE.2.2.69. 